\title{
RELATIONSHIP OF CUSTOMER RELATIONSHIP MANAGEMENT PRACTICES ADOPTED BY AIRLINES WITH LOYALTY OF PASSENGERS
}

\author{
Pawanjot Kaur
}

Research Scholar, School of Applied Management, Punjabi University, Patiala, India

\section{Dr. Sarang Narula}

Assistant Professor, School of Applied Management, Punjabi University, Patiala, India

\begin{abstract}
Customer Relationship management has become a crucial strategy which is adopted by every organization to improve its business and thus gaining competitive advantage over the rivals. The Indian Aviation is one of the largest growing sectors which laid attention on maintaining profitable relations with its passengers due to tremendous increase in passengers' traffic in the recent years. This paper assesses the effect customer relationship management factors adopted by Aviation sector on loyalty. The study uses seven customer relationship management factors -Customer focus, Responsiveness, Staff assistance, convenience, post-flight services, other relationship maintaining practices and needs of the customer based on the previous review of literature. Various statements related to relationship management practices were asked under each factor. The sample size consisted of 300 passengers from different districts of Punjab and Union Territory Chandigarh. Purposive non- probability sampling technique was used to select the target population for the survey. Structural equation modeling was employed to examine the relationship of the Customer Relationship Management factors on loyalty. The findings of the research shows that passengers have overall positive attitude towards Customer Relationship Management practices adopted by airlines and out of seven factors responsiveness, staff assistance, convenience, and other relationship practices factors have significant effect on passengers' loyalty. The research study suggested that airline should adopt appropriate relationship management strategies to develop long lasting relationship with the travelers thus result in loyalty towards the company.
\end{abstract}

Keywords: Customer Relationship Management, customer perception, customer loyalty, compound annual growth rate, Responsiveness. 
Cite this Article: Pawanjot Kaur and Dr. Sarang Narula, Relationship of Customer Relationship Management Practices Adopted by Airlines with Loyalty of Passengers, International Journal of Management, 11(6), 2020, pp. 2139-2148 http://iaeme.com/Home/issue/IJM?Volume=11\&Issue $=6$

\section{INTRODUCTION}

In present day's globalized and liberalized business environment, the service sector is experiencing stiff competition to meet the prerequisites of the clients and in this way achieving competitive edge over its competitors. With the accessibility of various alternatives, the customers are becoming more demanding and the organization has no choice but to respond to the customers' need faster or to lose them to the competitor. The aviation industry in India has raised as one of the fastest growing aviation markets in the world. With liberalization of this segment, the Indian aviation has witnessed a remarkable development in the last decade with robust growth in passenger and cargo traffic, gigantic increment within the non-scheduled operators and rapid increment in the range of operational airports within the country. The Growth in passenger traffic has been strong since the new millennium, especially with rising incomes and low-cost aviation. Credit Rating Information Services of India Limited (CRISIL) Research report estimates that there would be an increase of $2-3 \%$ in passengers' traffic at airports in the year 2020. It is also anticipated that over the year 2020-2025, the traffic at airports will expand at a compound annual growth rate (CAGR) of $11-13 \%$ because of faster growth in domestic passenger traffic at the rate of $12-14 \%$ even as worldwide traveler activity development drifts around 7-9\%. As per the statistics shown by Association of Private Airport Operator, Airports Authority of India the passenger traffic of India grew at 16.52 percent year on year to reach 308.75 million in the financial year (FY) 2018. The traffic grew at a compound annual growth rate of 12.72 percent during financial year 2006-2018. During April-August 2018 , domestic passenger traffic stood at 113.44 million while international traffic stood at 28.32 million. The Domestic passenger traffic grew by 18.28 percent to reach 243 million in the financial year 2018 and is expected to become 293.28 million in the financial year 2020E. The International passenger grew by 10.43 percent to reach 65.48 million in the financial year 2018 and traffic is expected to become 76 million in Financial year 2020 (Estimated)

\section{International and Domestic passenger traffic (million)}

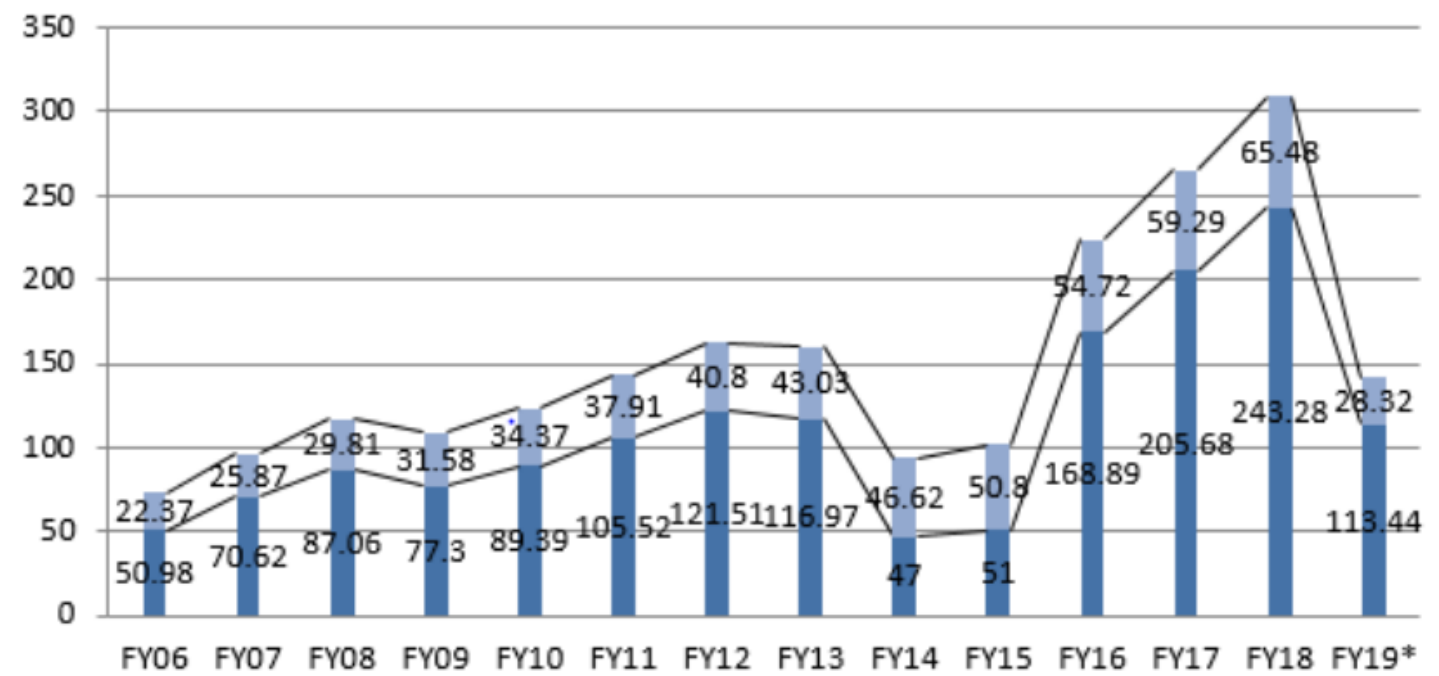

(Source: Airports Authority of India, Ministry of Civil Aviation) "FY- Financial Year

Figure 1 International and Domestic Passenger traffic (million) 
Over the financial year 2006-18, the Domestic passenger traffic expanded at a compound annual growth rate of 13.91 percent and International passenger traffic registered growth at a compound annual growth rate of 9.36 percent. These statistics on passengers growth indicated that airlines has become one of most preferable mode of travel despite other modes of transport because of convenience and fall in ticket prices due to existence of high competition among airline companies within the sector.

In this extremely competitive industry, while operational potency helps to reduce costs but customer satisfaction is the key to sustain market leadership and long-run profitability. Customer relationship marketing is the biggest paradigmatic shift in marketing theory and practice in the existing world. In the present era, customer relationship marketing plays a vital role in the success of every organization. The major goal of customer relationship marketing can be expressed as understanding the customers' needs and treating them better for increasing loyalty and profit (Velnampy and Sivesan, 2012). Customer relationship management assists the organization to build a better relationship with their customers by fulfilling their customer requirements. Proper implementation of customer relationship management would not only ensure customer delight but also increases customer satisfaction thus helps in maintaining their loyalty. The essence of CRM thinking originates from three concepts in marketing management: (1) customer orientation, (2) relationship marketing, and (3) database marketing. Airlines have realized the importance of having satisfied customers and are therefore focusing on customer relationship management (CRM) as a strategic tool for managing relationships with the customers. Customer Relationship Management in the Airline Industry includes all the touch points in the customer's travel experience. Customer Relationship Management in airlines starts much before a passenger board a flight; it starts as soon as a passenger comes in contact with a particular airline and continued up to post-flight services. Customer relationship management in passenger airlines extends beyond traditional sales, service, marketing, and loyalty to include all of the touch points in a passenger's travel experience. Customer Relationship Management in the airline sector is different from other service sectors because of its diversified nature of customer interaction and operations. The main domains covered in the airlines relationship practices are- Pre-travel activities, On- Board and Post-travel practices.

\section{REVIEW OF LITERATURE}

Kabiraj et al. (2004) conducted a study to develop and design strategic business models for customer relationship management for retail banking in India. A self- structure questionnaire was formulated and pre-tested before gathering information. Exploratory research was conducted to collect secondary data and three sets of a pre-tested questionnaire were designed to collect data from sets of respondents - Customer Relationship Management end users, retail bank customers, and Customer Relationship Management vendor or application service providers. Non- probability convenience sampling was used for data collection from 20 banks (10 private sector banks and 10 public sector banks). A sample of 200 customers, 10 from each bank was selected. Factor analysis identified three factors - the level of awareness, offered facilities and degree of satisfaction. The result of Z- test showed that the facilities offered by banks to the customers have increased after implementation of Customer Relationship Management strategy. The level of satisfaction among the customers was more in private banks than public banks. In the second part of study 15 industries were selected with two samples from each industry were selected randomly. The data was again subjected to factor analysis and Z- test. Six factors were identified- frequency of application and awareness, type of involvement, obtained benefits, time span, customer satisfaction, and business objectives. It was concluded that Customer Relationship Management system development and implementation are a key priority for most modern Indian retail banks. 
Talet et al. (2011) analyzed the customer satisfaction perception of Customer Relationship Management and loyalty levels in the mobile telecom companies in Saudi Arabia. A sample of 441 mobile telecom customers was surveyed to investigate their opinion about the quality of offered customer services by mobile telecom companies and its impact on customer satisfaction. The study concentrated on three main channels used by mobile companies to provide customer services (customer service offers, phone operator and website services). The empirical findings presented the evidence that the quality of customer service significantly affects customer satisfaction and customer loyalty. It was found that the majority of customers preferred to use phone operator than office customer services.

Saadat and Nas (2013) studied the impact of customer relationship management on customer loyalty in the cellular industry in Pakistan. The study considered five firms- Ufone, Mobilink, Telenor, Warid, and Zong. A structured questionnaire was used to collect data from 150 respondents. The research design used was descriptive in nature. A theoretical framework covering independent variables (store environment, service quality within the retail outlet, service quality on helpline and price) was adopted to study the impact on customer relationship management which has a significant impact on customer loyalty. The population selected for the study was university students and staff members in Kohat, Pakistan. Correlation and regression analysis methods were used for the analysis of data. It was concluded from the analysis that CRM has a positive and significant impact on customer loyalty. It not only maintains customers' records but also provides additional value-added services. It was suggested that marketers should emphasize on store environment and service quality because in a comfortable store environment consumers are willing to spend extra time which increases chances too but more for best services.

Aladwan and Hersh (2014) analyzed the impact of E-CRM on customer loyalty in Airline companies in Jordan. Data was collected through a questionnaire survey of airline companies. A sample size of 513 passengers was used. Hierarchical regression analysis was applied to study a significant relationship. Three functions were considered while studying the impact Communication function, transaction function, and relational function. The study indicated that communication function has strong relationsips through the company's website have an important and effective role in creating the customers' loyalty in the airline industry. It was also found that interactive function played an important role as it was important that the company's website must be easy to navigate moreover security also lead to loyalty. It was also found that there exist differences in the impact of customers' electronic relations management on customer loyalty due to educational level and experience.

Malik (2015) analyzed the impact of Customer Relationship Management benefits on customer loyalty and retention in the automobile sector in India. The research was conducted through a survey method and data was collected from vehicle owners. The descriptive research design was used in the study. Stratified Non- probability sampling method was used to draw a sample of 120 respondents from the national capital region (NCR) of India. The validity of the questionnaire was done to check whether the variables used to study Customer Relationship Management dimensions produce consistent results (Cronbach alpha 0.745). Factor analysis has been administered to narrate the variable in different dimensions of customer relationship management in the automobile sector. Exploratory factor analysis was used to identify the underlying constructs and investigate relationships among the variables. Regression analysis and $\mathrm{F}$ test were also carried out on the data collected. The results revealed that significant factors like time service delivery, promptness in handling repair work, friendliness helpfulness, and arranging replacements lead to customer loyalty in the automobile industry. 


\section{RESEARCH DESIGN AND METHODOLOGY}

To achieve the objectives of the study both primary and secondary data collection was carried out. The primary data was collected with the help of well-structured questionnaires which were distributed to target respondents to get their opinion. The secondary data was collected from various research papers, books, published journals published, and Directorate General of Civil Aviation reports, annual reports of the civil aviation sector and official websites of various airlines. The main objective of this research is to analyze the effect of Customer relationship management factors on the passengers' loyalty. In this study, survey method was adopted according to which a questionnaire was designed as a tool to collect primary data from 300 passengers of airlines in Punjab and Chandigarh.

\subsection{Instrument Design}

To analyze the relationship between loyalty and Customer Relationship Management program, the questionnaire was developed. The original questionnaire included 44 statements as independent variables to be classified under Customer Relationship Management factors based on prior studies available. To examine the underlying factors that make up the sub-dimension and to test validity of model exploratory factor analysis and Confirmatory factor analysis were employed and the questionnaire was refined containing 41 statements which were categorized under seven factors.

\subsection{Sample size and Data Collection}

The sample size consists of 300 passengers belonging to different gender, age, income categories and professions. The passengers were the individuals who have travelled through airlines either domestic or internationally. The sample size was selected keeping in mind the research objectives and constraints. Non-probability sampling technique was used to select the respondents of the study and the main goal to use this sampling was to focus on particular characteristics of a population that is of interest thus enabling to answer the research questions of the study. Five-point likert scale was used to measure the responses. Respondents were asked to respond to each statement on the basis of 1 to 5 scales.

\section{DATA ANALYSIS}

This study initially used 44 statements under six customer relationship management factors to identify the relationship of perception with passengers' loyalty in airline companies. These statements were classified under various factors based on literature reviews which are discussed below:

Table 1 showing factors formed based on literature review

\begin{tabular}{|l|c|}
\hline \multicolumn{1}{|c|}{ Factors } & No. of statements \\
\hline Customer Focus & 12 \\
\hline Responsiveness & 7 \\
\hline Staff Assistance & 9 \\
\hline Convenience & 7 \\
\hline Post- Flight services & 4 \\
\hline Other relationship maintaining practices & 5 \\
\hline
\end{tabular}

To examine these and to test validity of model exploratory factor analysis and Confirmatory factor analysis were employed. Exploratory and confirmatory factor analysis was used to refine various statements under different factors. Exploratory factor analysis was performed on 44 statements. To justify the application of Exploratory Factor Analysis in this study, according to 
Hair et al. (2006) the measure of sampling adequacy was utilized. Hence, the Bartlett's Test of Sphericity (Bartlett's Test) and Kaiser-Mayer-Olkin (KMO) indicate the measure of sampling adequacy. Factor analysis under the extraction method of principal component analysis with the rotation method of varimax with Kaiser Normalization was employed. The dimensions of the scale were examined by factor analyzing the items using the principal components analysis with Varimax rotation. The rotated components matrix showed there were a few items with nosignificant loadings in any of the components, so non-loading items were dropped and the Exploratory Factor Analysis (EFA) was performed again until all the items were loaded into the respective component. Two statements- one under Customer Focus and one other relationship practices were excluded due to insignificant values. After re-running Exploratory Factor Analysis, seven factors were extracted which explained $69.67 \%$ of total variance. One new factor was created which was named Needs of the customer and there were three statements from earlier factors (one from Customer focus factor and two from Staff Assistance factor) placed under it.

Confirmatory factors analysis was carried out on all the statements extracted from exploratory factor analysis. There were 42 statements whose values found to be significant and Confirmatory Factor Analysis was run on it. Confirmatory Factor Analysis excluded seventh statement of Convenience factor (C7) due to low standardized factor loading. The statements with lower factor loading were excluded to yield better results.

After factor analysis, the research instrument was tested for its reliability. The internal consistency of the grouping of the items was estimated using the reliability co-efficient called Cronbach's alpha. In the study, internal consistency for all factors was calculated. The Cronbach's $\alpha$ values of all the seven extracted factors ranges from 0.82 to 0.95 , which suggests that scale has good internal consistency.

Table 2 represents reliability analysis of all factors extracted

\begin{tabular}{|l|c|c|}
\hline \multicolumn{1}{|c|}{ Factor } & No. of items & Cronbach's Alpha \\
\hline Customer Focus & 10 & 0.91 \\
\hline Responsiveness & 7 & 0.92 \\
\hline Staff Assistance & 7 & 0.95 \\
\hline Convenience & 7 & 0.91 \\
\hline Post flight services & 4 & 0.82 \\
\hline Other practices & 4 & 0.93 \\
\hline Needs of the customer & 3 & 0.83 \\
\hline
\end{tabular}

The fitness of the model was tested. It shows that Goodness of Fit Index (GFI) obtained was 0.83 as against the recommended value of above 0.80; The Adjusted Goodness of Fit Index (AGFI) was 0.81 as against the recommended value of above 0.80 as well. The Comparative Fit Index (CFI) and Tucker-Lewis Index (TLI) were 0.91 and 0.91 respectively as against the recommended level of above 0.90 . RMSEA was 0.06 and is well below the recommended limit of 0.08, and Root Mean Square Residual (RMR) was also well below the recommended limit of 0.08 at 0.05 . Hence the model shows an overall acceptable fit. The confirmatory factor analysis showed an acceptable overall model fit and hence, the theorized model fits well with the observed data. It can be concluded that the CFA model fits the sample data very well. 
Relationship of Customer Relationship Management Practices Adopted by Airlines with Loyalty of Passengers



Figure 2 showing output of Confirmatory Factor Analysis

Table 3 Fit statistics of the Measurement model

\begin{tabular}{|l|c|c|}
\hline \multicolumn{1}{|c|}{ Criterion } & Obtained Value & Accepted Value \\
\hline CMIN & 1845.012 & \\
\hline D.F. & 758 & $\leq 0.05$ \\
\hline P- Value & 0.00 & $\leq .3$ \\
\hline CMIN/DF & 2.43 & $\geq .80$ \\
\hline GFI & .83 & $\geq .90$ \\
\hline CFI & .91 & $\geq .90$ \\
\hline TLI & .91 & $\geq .80$ \\
\hline AGFI & .81 & $\geq .50$ \\
\hline PGFI & .73 & $\leq .08$ \\
\hline RMR & .05 & $\leq .08$ \\
\hline RMSEA & .06 & \\
\hline
\end{tabular}

\subsection{Demographic profile of the passengers}

The respondents selected for the study belonged to different categories on the basis of sex, age, education, monthly income and frequency of travel. The passengers' belonging to different categories may have different perceptions regarding the customer relationship practices followed by airline companies. The results revealed that the numbers of male respondents (224) are more than the females (76) in the study. The age distribution of the respondents exhibits that out of 300 respondents, majority of the respondents 118 belongs to age group between 46 $-65 \mathrm{yrs}$. There were 111 respondents which fall in 25-45 yrs age group and minimum number 
of respondents belongs to below 25 years age group i.e. 18 . The education and monthly income distribution of the respondents was also displayed in the research work. It shows that highest number of the respondents who participated in the survey are undergraduate and having Bachelor's degree. It is evident from analysis that as there were four categories to estimate monthly income of respondents, maximum respondents i.e. 138 which constitutes about $46.0 \%$ of total sample belong to Rs.80,000-1,20,000 monthly income category and there are only 37 $(12.3 \%)$ of respondents which have monthly income more than Rs. 1, 60,000. The frequency of travelling indicates that there are 146 passengers who prefer to travel annually by airlines followed by 89 who travel after every 6 months and 43 respondents travel on certain occasions.

\subsection{Relationship of Customer Relationship Management practices on Customer Loyalty in the aviation sector}

With the availability of various alternative and increase in the amount of accessible information in recent years, the conscious level of customers has improved continually. In the present era, the customers are aware of the power they have on the market and that every activity is realized for them. Before choosing a product or service, consumers look at the price, features, accessibility of the product and the additional services offered to them. Today firms have entered into an effort to present at a lower cost than their rivals the products and services that can meet the customer wishes and expectations fully so that they can render customers more loyal.

A loyal customer is committed to continuing long-term relations with the present provider. Customer loyalty is a purchase behavior instead of an attitude. The behavioral and attitudinal dimensions used in the study are consistent with the operationalization of the factors of customer loyalty specified in the behavioral intention battery of Zeithaml et al., (1996). The items used for the study for measuring customer loyalty included:

- Saying positive things about the firm;

- Recommending the firm to others;

- Considering the firm as the first choice for future business; and

- Doing more business with the firm in the future.

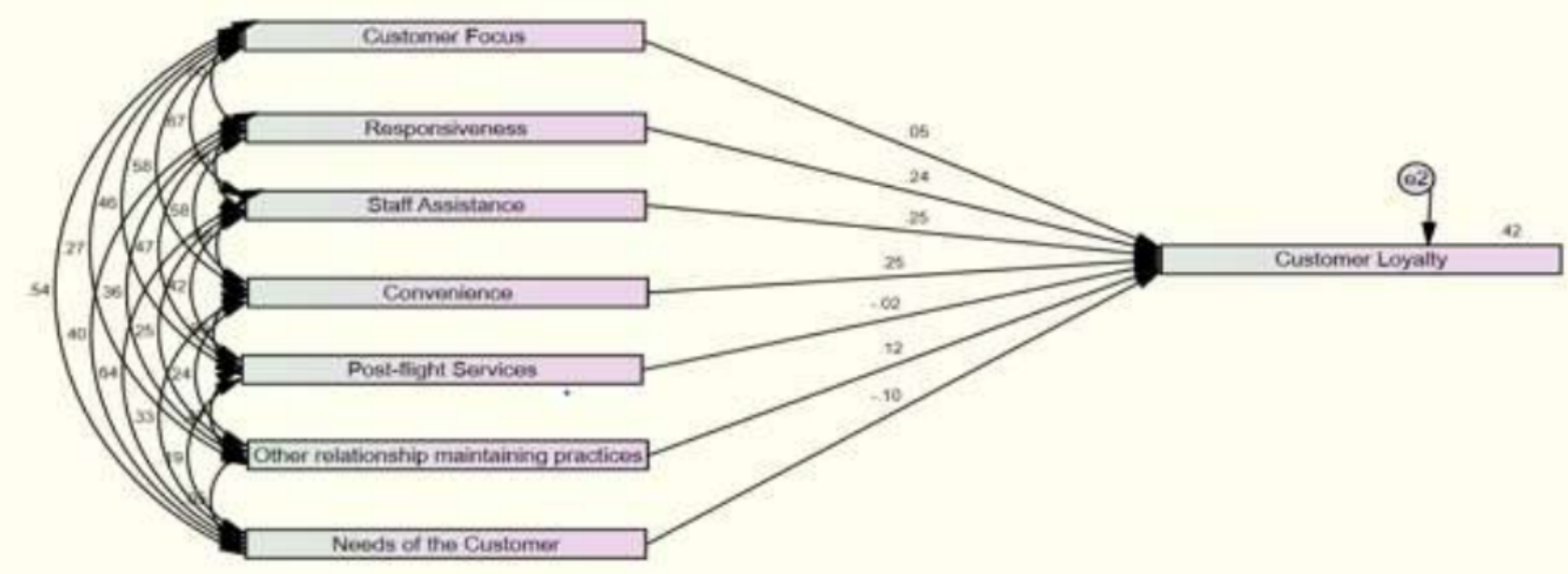


Relationship of Customer Relationship Management Practices Adopted by Airlines with Loyalty of Passengers

Figure 3 Relationship analysis between CRM factors and Customer Loyalty

Table 4 Relationship analysis between CRM factors and Customer Loyalty

\begin{tabular}{|l|c|c|c|c|}
\hline \multicolumn{1}{|c|}{ Factors } & $\begin{array}{c}\text { Standardized } \\
\text { Coefficient } \boldsymbol{\beta}\end{array}$ & S.E. & C.R. & Sig. \\
\hline Customer Focus & .05 & .11 & .79 & .43 \\
\hline Responsiveness & .24 & .10 & 3.88 & .00 \\
\hline Staff Assistance & .25 & .11 & 3.58 & .00 \\
\hline Convenience & .25 & .09 & 3.86 & .00 \\
\hline Post-flight Services & -.02 & .07 & -.28 & .78 \\
\hline $\begin{array}{l}\text { Other relationship } \\
\text { maintaining practices }\end{array}$ & .12 & .06 & 2.25 & .02 \\
\hline Needs of the customer & -.10 & .09 & -1.67 & .09 \\
\hline
\end{tabular}

Table 5 Squared Multiple Correlations: (Group number 1 - Default model)

\begin{tabular}{|l|c|}
\hline & Estimate \\
\hline Customer Loylaty_Total & .42 \\
\hline
\end{tabular}

The results indicated that the model explained 42 percent variation in customer loyalty due to Customer Relationship Management factors. The analysis provides that relationship measure has an average effect on customer loyalty. Customer loyalty is positively affected by customer focus, responsiveness, staff assistance, other relationship practices, and convenience, whereas post-flight services and needs of the customer have negatively affected overall customer loyalty for airlines. This means that if the customers of airline companies are satisfied by the overall Customer Relationship Management practices offered by their company, they will continue to do business with the company and prefer to travel with the same airlines. This also suggests that when airlines lack in providing post-flight services and will not take steps to keep in touch with the customers then this will lead to dissatisfaction thus have a negative impact on customer retention. The significance value of responsiveness, staff assistance, convenience, and other relationship practices is $0.00(<0.05)$ which represents that these factors have a significant effect on customer loyalty in the airline industry. Further the results showed that the factors, Customer focus with a p-value of $0.43(>0.05)$, Post-flight services with a p-value of $0.78(>0.05)$ and needs of the customer with p-value $0.09(>0.05)$ indicates an insignificant effect on passengers' loyalty.

\section{CONCLUSION AND SUGGESTIONS}

The study represents that Customer relationship management factors has largely influence the loyalty of the travelers. The significance value of responsiveness, staff assistance, convenience, and other relationship practices is $0.00(<0.005)$ which represents that these factors have a significant effect on customer loyalty in the airline industry. The results indicated that if firms strive to maximize their customer share and create affectively committed customers then it is recommended that they should implement loyalty program and implement direct mailings system that provide economic incentives. These types of strategies could result in positive effects in the long run on customer retention and customer share development. The main principle of Customer Relationship Management is to focus on the most loyal customers. 
However, improving share for loyal customers is much more difficult, because they have a greater tendency to reduce their shares in the future.

\section{REFERENCES}

[1] Aladwan, K. and Hersh, A. (2013). The impact of E- CRM on the customer loyalty of airline companies: Field study in Jordan market. European Journal of Business and Management, 6(9), $1-7$.

[2] CRISIL Sector Report: Airport Infrastructure, March 2020 Retrieved from: https://www.crisil.com/en/home/our-analysis/reports/2017/08/sector-report-airport infrastructure.html

[3] Gures, N., Demirer, H., \& Kara, M. (2009). European passengers' satisfaction and fairness perceptions about Turkish airports. International Business \& Economics Research Journal, $8(10), 43-52$.

[4] Gwinner, K.P., Gremler, D.D. and Bitner, M.J. (1998). Relational benefits in services industries: The customer's perspective. Journal of Academy of Marketing Science, 26(2), 101-114.

[5] Hair, J.F.,Black,W.C., Babin, B.J., Anderson,R.R., \& Tatham, R.L. (2006). Multivariate Data Analysis, Sixth Edition, Pearson Education Limited.

[6] Kabiraj, S., Agrawal, D.P., \& Singh, D. (2004). Customer relationship management practices in retail banking: An Indian experience. International journal of Effective Management, 1(1), 121.

[7] Liau, B.Y., \& Tan, P.P. (2014). Gaining customer knowledge in low cost airlines through text mining. Industrial Management \& Data Systems, 114(9), 1344-1359.

[8] Malik, G. (2015). Impact of customer relationship management on customer loyalty and customer retention with reference to automobile sector. University Journal of Research, 1(1), 70-89.

[9] Mentzer, J. T., Bienstock, C. C., \& Kahn, K. B. (1995). Benchmarking satisfaction: Market leaders use sophisticated processes to measure and manage their customers' perceptions. Marketing Management, 4 (a), 45-46.

[10] Oliver R.L. (1999). Whence customer loyalty? Journal of Marketing, 63, 33-44.

[11] Parasuraman, A., Zeithaml, V. A., \& Berry, L. L. (1987). Customer-oriented corporate cultures are crucial to services marketing success. Journal of Services Marketing, 1 (summer), 39-46.

[12] Reichheld, F.F. (1993). Loyalty-Based Management. Harvard Business Review, 2, 64-73.

[13] Reports retrieved from https://www.aai.aero/

[14] Saadat, N. and Nas, Z. (2013). Impact of customer relationship on customer loyalty in cellular industry: Evidence from KPK, Pakistan. Asian journal of Management sciences and education, 2(3), 20-30.

[15] Talet, A.N., Shawosh, M.H., \& Saeed, S.A. (2011). The perception of customer relationship management adoption case of mobile companies in Saudi Arabia. Journal of Mobile Technologies, Knowledge \& Society, 1-13.

[16] Velnampy, T., \& Sivesan, S. (2012). Customer relationship management and customer satisfaction: A study on mobile service providing companies in Srilanka. Global Journal of Management and Business Research, 12(18), 1-7.

[17] Zeithaml, V.A. and Berry, L.L. and Parasuraman, A. (1996). The Behavioural Consequences of Service Quality. Journal of Marketing, 60, 31-46. 